\title{
Article
}

\section{Assessing the effectiveness of the UK's insolvency regulatory framework at deterring insolvency practitioners' opportunistic behaviour}

Wood, John

Available at http://clok.uclan.ac.uk/25188/

Wood, John ORCID: 0000-0001-7542-9934 (2019) Assessing the effectiveness of the UK's insolvency regulatory framework at deterring insolvency practitioners' opportunistic behaviour. Journal of Corporate Law Studies, 19 (2). pp. 333-366. ISSN 1473-5970

It is advisable to refer to the publisher's version if you intend to cite from the work. http://dx.doi.org/10.1080/14735970.2018.1554551

For more information about UCLan's research in this area go to http://www.uclan.ac.uk/researchgroups/ and search for <name of research Group>.

For information about Research generally at UCLan please go to http://www.uclan.ac.uk/research/

All outputs in CLoK are protected by Intellectual Property Rights law, including Copyright law. Copyright, IPR and Moral Rights for the works on this site are retained by the individual authors and/or other copyright owners. Terms and conditions for use of this material are defined in the policies page. 
John M. Wood

Lancashire law School, University of Central Lancashire, Preston, UK

Email: jwood12@uclan.ac.uk; LinkedIn: linkedin.com/in/woodlaw

ORCID: https://orcid.org/0000-0001-7542-9934 


\title{
Assessing the effectiveness of the UK's insolvency regulatory framework at deterring insolvency practitioners' opportunistic behaviour
}

\author{
John M. Wood ${ }^{1}$
}

\begin{abstract}
This article examines whether the increase in insolvency regulation is adequate to deter insolvency practitioners from using their discretion to charge excessive fees. To understand how insolvency regulation has developed the article will commence with a review of the historical origins of insolvency work and how it became associated with opportunistic behaviour. Next, the insolvency practitioner will be examined along with the recognised professional regulators to examine how their practices have helped to shape insolvency law. IP discretion and their decision making will then be considered to demonstrate how opportunism has continued to exist in administration, before the measures that have been taken over the last twenty years to address some of these issues are explored. The Australian regulatory system will then be reviewed as a comparison to the UK, before finally recommendations are made to the effect that insolvency practitioners should be further monitored in the use of their discretion.
\end{abstract}

\footnotetext{
${ }^{1}$ Lecturer in Law, Lancashire Law School, University of Central Lancashire. I am grateful to Professor Peter Walton, for his insightful comments on an earlier draft of this article. I am also grateful to the ILA Academic Forum 2017 for the comments received during the presentation of this work, in addition to the suggestions received from the anonymous reviewer. Any errors are entirely with the author.
} 


\section{Introduction}

In recent years the $\mathrm{UK}^{2}$ has sought to significantly revise its approach to how Insolvency Practitioners ("IPs") operate within the insolvency market. Following a wave of highly influential reports into the adequacy of the insolvency regulatory regime, it was identified that reform was required in a number of key areas. For the purpose of this article the focus is on two key aspects; the inadequate regulation that facilitates the over-charging of fees by IPs; and other regulatory shortcomings that have led to complaints being made against IPs. In regards to the over-charging of fees it is essential to reduce this to two distinct sub-issues: (a) the deliberate taking of excessive fees, and (b) charging in accordance with industry norms which results in the taking of excessive fees. While subsequent legislation has addressed some of these issues, in particular the concerns relating to excessive fees, it is questioned whether it have been adequate and effective in preventing opportunistic behaviour within the insolvency industry. ${ }^{3}$ The main legislation in question has followed in the form of the Small Business, Enterprise and Employment Act (SBEEA) 2015; the Regulatory Objectives and Oversight Powers 2015; and the Insolvency (England and Wales) Rules 2016. ${ }^{4}$ Although these recent developments suggest that both the Insolvency Service, in its capacity as the oversight regulator, and the regulators of the IPs (the Recognised Professional Bodies hereafter "RPBs"), are willing to modify insolvency practice, the level of progress has been slow.

The gradual and somewhat reluctant progression within the insolvency industry has often been prompted into action by the need to avert criticism received from creditors, successive governments, and the media alike. ${ }^{5}$ However, despite the criticism the responsive measures aimed at modernising insolvency regulation have purposely retained the wide discretion that permits IPs to define the scope of their work. The high level of discretion when applied to a commercial environment provides IPs with the autonomy to make decisions that are often difficult for others to challenge. This position has been fortified by the courts who are generally reluctant to contest decisions that were based on commercial factors. Thus, little

\footnotetext{
${ }^{2}$ In this article the UK will refer to England and Wales.

${ }^{3}$ This article refers to the purpose of administration as an example to answer this question.

${ }^{4}$ Which has been in force since April 2017.

${ }^{5}$ Most of the criticism has concerned the lack of accountability and transparency in the existing insolvency regulatory framework. See, J Hurly and A Ralph, 'ACCA faults lead to warning about insolvency regulation' (Times, $3^{\text {rd }}$ October 2016) <http://www.thetimes.co.uk/article/government-blows-whistle-on-regulators-owngoals-m3t97xx6p> accessed 31 March 2018.
} 
scope has been left for creditors to challenge IP decisions, thereby leaving open the possibility for an IP to engage in what could be viewed as opportunistic behaviour - conduct that leads to their position (directly or indirectly) being enhanced, usually through the inflation of their fees.

To consider this possibility, the article will consist of eight parts. In part one, the article will commence with a brief introduction, before turning to the second part of the article that explores how the accountant-driven nature of the IP has influenced the way that IPs operate within the insolvency market. It will also be considered how the respective RPBs have responded to any breaches that may have been committed by its members. Part three questions the purpose of administration and how the imprecise wording of the first objective - rescue the company as a "going concern" - permits its manipulation by IPs with a view to securing high fees. Part four reviews the recent regulatory developments that have occurred and how they could shape the existing regulatory framework. Part five will examine the Code of Practice used in Australia, and whether the UK would benefit from adopting a similar model. Part six will make recommendations for legislative change to address the concerns regarding fees and regulation. Part seven sets out the conclusions. Ultimately, the article acknowledges the need for IP discretion within the insolvency industry so that commercial decisions can be made, but it is noted that the use of discretion must be suitably regulated to ensure that it is not misused.

\section{Shaping insolvency law: The role of insolvency practitioners and their professional regulators}

In an insolvent company an IP is afforded the discretion to make the necessary commercial decisions for the purpose of attaining the best result for the creditors as a whole. Since the IP can go about their duties as they see fit, it is their professional discretion that has helped to shape insolvency practice. ${ }^{6}$ To appreciate how this discretion could be used to encourage opportunistic behaviour, the administration procedure, along with limited references to liquidation will be referred to. However, before this is examined it is first necessary to take a closer look at the historical approach to insolvency.

\footnotetext{
${ }^{6}$ The courts have often held the traditional approach that they would not interfere with a commercial decisions made by an office holder, see generally Re CE King Ltd [2000] 2 BCLC 297, 202-3; Re T\&D Industries Plc [2000] 1 WLR 646, 657; Re MF Global UK Limited [2014] Bus LR 1156 [41].
} 


\subsection{A brief historical overview on the development of insolvency work}

It is critical to appreciate that the composition of IPs principally consist of accountants and some solicitors, with the former virtually having a monopoly on insolvency related matters. ${ }^{7}$ It is the strong traditional association between accountants and insolvency work that has shaped insolvency law, particularly at the beginning of the $20^{\text {th }}$ century. ${ }^{8}$ Solicitors, given their ambivalent moral and social position were conscious of the stigma associated with insolvency related work. ${ }^{9}$ However accountants on the other hand, despite the introduction of the Joint Stock Companies Act 1844, were not in a financially strong position to turn down such an opportunity given the slow growth of business. Despite the initial reluctance to turn to this type of work, corporate insolvency provided an immense opportunity to many accountant firms. ${ }^{10}$ The financial profit that was realised from this work soon meant that the majority of the fees billed by accountancy firms were from insolvency related cases. ${ }^{11}$ Over time, the wealth generated from insolvency fees became heavily relied upon and accountants steadily grew a reputation for being "men of business" who could seek out profitable opportunities in failed companies. ${ }^{12}$

Given the often complex nature of insolvency matters, the company information obtained by IPs could often be subject to wide interpretation. Such a practice left open the possibility that IPs could exercise their wide discretion and with it mould the applicable insolvency laws to achieve their desired result. This would have been particularly evident in classic administration when a decision was required to determine which objective would form the purpose of administration. Common practice within the insolvency industry would suggest that the determination of this objective would have been secondary to the IP's primary function as accountants. In other words, since the purpose of administration could only have

\footnotetext{
${ }^{7}$ There are approximately 1,750 Licensed Insolvency Practitioners in the United Kingdom, not all of whom take appointments - various lawyers hold licences but rarely use them to take appointments, preferring to advise other practitioners.

${ }^{8} \mathrm{C}$ Napier and C Noke 'Accounting and law: A Historical Overview of an Uneasy Relationship', in M Bromwich and A Hopwood 'Accounting and the Law' (edn), (London: Prentice Hall, 1992) 34.

${ }^{9}$ W R Prest, 'Introduction', in W Prest, Lawyers in Early Modern Europe and America, (edn), (Croom Holm, 1981).

${ }^{10}$ See P Arnold, C Cooper and P Sikka, Insolvency, Market Professionalism and the Commodification of Professional Expertise' (British Accounting Association Conference, HeriotWatt University, 2005) 9-12.

${ }^{11}$ See E Jones, Accountancy and the British Economy 1840-1980: The Evolution of Ernst and Whinney (B. T. Batsford Ltd, 1981).

${ }^{12}$ Certified Accountants' Journal, 'Are lawyers Business Men?' (1910) 37 Certified Accountants' Journal 105107, 105.
} 
been determined when the financial accounts were complete, ${ }^{13}$ there would be an opportunity for the IP to make an assessment that favours their own position. Such an assessment ensures that opportunistic behaviour remains integrated in IP culture.

To determine how competent an IP would be in managing the technical aspect of the job should not be assessed on the basis of the professional status that they enjoy as a result of their occupation. ${ }^{14}$ An IP must not only pass the relevant exams, but they must also satisfy other criteria. The Insolvency Act 1986 requires the RPBs to ensure that their members are fit and proper individuals, who are licensed to act as IPs, and possess the necessary experience and qualifications to undertake insolvency work. ${ }^{15}$ In addition, there is also a Memorandum of Understanding in place between the RPBs ${ }^{16}$ and the Secretary of State to ensure that the qualification requirements for IPs are met, and that common professional and ethical standards are followed. The professional and ethical considerations are set out by the Insolvency Service, on behalf of the Secretary of State, who work with the insolvency industry to establish both the Insolvency Code of Ethics, ${ }^{17}$ and the Statements of Insolvency Practice (SIPs), ${ }^{18}$ all of which must be followed by the IP.

However, despite the insolvency industry's attempt to harmonise the practice of IPs, the discretion afforded to IPs has resulted in the possibility of inconsistent outcomes emerging when similar cases were reviewed. The use of qualifications and experience to measure competence and quality in the industry is no different to many other professions, but it does ignore another important issue such as the highly emotive situations that the IP may find themselves in, and the influence that this may have on their decision-making.

\footnotetext{
${ }^{13}$ See J Flood and E Skordaki, 'Insolvency Practitioners and Big Corporate Insolvencies' (1995) ACCA: Research Project 43, 6.

${ }^{14}$ T Jones, 'Understanding Management Accountants: the rationality of Social Action', (1992) Critical Perspectives in Accountancy 225, 230.

${ }^{15}$ ss391 and 393 of the Insolvency Act 1986.

16 Since September 2016, there are now five bodies as the Law Society of Scotland and the SRA had ceased to authorise IPs by the end of 2015. The current list of RPBs include: Institute of Chartered Accountants in England \& Wales (ICAEW); Insolvency Practitioners Association (IPA); Institute of Chartered Accountants of Scotland (ICAS); Association of Chartered Certified Accountants (ACCA); Institute of Chartered Accountants in Ireland (ICAI).

${ }^{17}$ For further information see $<$ http://www.bis.gov.uk/insolvency/insolvencyprofession/Professional\%20conduct/code-of-ethics> accessed 3 March 2018.

${ }^{18}$ See R3 website for the updated versions <https://www.r3.org.uk/what-wedo/publications/professional/statements-of-insolvency-practice/e-and-w> accessed 3 June 2018.
} 
While it has been established that an IP is a highly qualified professional, with it being a requirement to pass the JIEB exams before they could be appointed as an IP, ${ }^{19}$ there is a genuine concern whether IPs are fully prepared for the intensity of the role. In particular, little could be done to prepare IPs for dealing with the high emotions of individuals who may have been affected by the insolvent company. In insolvent companies where there were competing creditor interests, it would be natural to expect complaints to arise from the work undertaken by IPs. Minor complaints would often be resolved without the need for further action, but any issues that could not be resolved between the IP and the concerned party would be directed to the Gateway. If the Gateway concluded that the complainant's case contained some merit, then this would have been referred to the relevant RPB to investigate, and if necessary, provide a suitable sanction against the IP in question. How precisely the RPBs deal with complaints has been the source of much deliberation. But before this can be explored in greater detail it is necessary to appreciate the role and powers of the IP.

\subsection{The insolvency practitioner}

IPs are highly trained individuals who are licensed and authorised to act in relation to an insolvent company. ${ }^{20}$ As office holders, they are expected to provide advice on all insolvency related matters, and undertake appointments in all formal insolvency procedures. ${ }^{21}$ As part of their role they are assigned the duty to decide the best course of action in dealing with a financially distressed company. ${ }^{22}$ Factors that influence their decisions typically go beyond their statutory duties, with which they are expected to be familiar, to include fiduciary duties such as to act equitably and ethically. ${ }^{23}$ The importance of these fiduciary duties is realised when it is understood that they have helped to underpin the approach of the courts to

\footnotetext{
${ }^{19}$ The average pass rate for successful candidates was at $23 \%$. The average age of the candidates was at 33 years old.

${ }^{20}$ A distinction should be made between turnaround specialists and IPs with the former not being subject to any mandatory regime of training, experience or qualification and they do not have to comply with a system of accreditation. See generally, V Finch, 'Doctoring in the Shadows of Insolvency' (2005) JBL 690, 696.

${ }^{21}$ Company Voluntary Arrangements, and receiverships are beyond the scope of this article since they were identified as procedures that attracted little criticism when it came to the fees charged. See Kempson Report, 2.

22 In corporate insolvency, IPs are invariably installed as agents of the company (for confirmation of this with regard to administrative receivers and administrators see for example s44(1)(a) and para 69 of Schedule B1 of the Insolvency Act 1986). Significant modern authorities confirming this position in the case of receivers Mills $v$ Birchall [2008] BCC 471, and also liquidators Gagen Sharma v Top Brands Limited [2015] EWCA Civ 1140.

${ }^{23}$ Ethical behaviour can include to avoid acting unconscionably, see Horler v Rubin [2011] BPIR. 718. See also, I Dawson 'Corporate rescue by the upright rescuer - a trap for the unwary' (2016) 29(6) Insolvency Intelligence 81-86.
} 
remuneration questions. ${ }^{24}$ The court places the almost unfettered decision making powers with the IP but it is expected that they use their discretion in a manner that is compliant with the general statutory provisions contained within the Insolvency Acts, as well as the relevant SIPs and the Code of Ethics. ${ }^{25}$ Collectively, the requirements ensure that the IP considers the creditors as a whole, a position that has subsequently provided protection for IPs against disgruntled unsecured creditors who may have felt that their interests had not been considered. While the IP may be subject to sanctions for falling below the "fit and proper" standard, few cases have resulted in any action being taken by the RPBs. ${ }^{26}$ The RPBs reserve wide discretion to decide what sanction, if any, to give to their members, and the decisions that they reach would rarely be challenged by the courts since they are reluctant to question the commercial decisions made by IPs. ${ }^{27}$

The courts have been consistent in applying this approach, which has in turn led to some inconsistencies being tolerated in the industry. ${ }^{28}$ For example, the IPs' wide decision-making powers affords them the discretion to determine the outcome of an administration procedure without attracting much scrutiny. This presents the IP with an opportunity to shape the company's future, an act that has been made possible due to the indistinct terminology of key provisions within certain insolvency procedures. For instance, the primary objective of administration (as stated in paragraph 3 of Schedule B1 of the Insolvency Act 1986) is to rescue the insolvent company as a going concern. However, efforts to define what the purpose and extent of "going concern" is can be widely interpreted. A company that has been substantially downsized could still be classed as being rescued despite it not resembling anything of its former self. The extent and type of change that the company would require to survive would largely depend on the circumstances and the intention of the IP, meaning that

\footnotetext{
${ }^{24}$ See H Anderson, The Framework of Corporate Insolvency Law (OUP 2017), 120.

${ }^{25}$ The influence of the Code of Ethics on IP behaviour will be discussed in a separate article.

${ }^{26}$ See the Insolvency Service's 2015 Annual Review of Insolvency Practitioner Regulation (March 2016) 10, 16-

18. The sanctions applied in 2016 follow a similar pattern with professional competence and due care remaining a key breach upon which complaints are brought.

27 See Re Longmeade Ltd (In Administration) [2016] EWHC 356 (Ch); [2016] BLR 506. The exception tends to be where is it evident that the administrator has erred in law or are notably unfair to one or more creditors, see Re CE King Ltd [2000] 2 BCLC 297; BLV Realty Organization Ltd v Batten [2009] EWHC 2994 (Ch); [2010] BPIR 277. Also note Beattie v Smailes [2011] EWHC 1563 (Ch); [2012] BCC 205, which dismissed 'extravagant' costs claimed by the joint liquidators.

${ }^{28}$ Such inconsistencies include the topic of officeholder remuneration and the closely associated topic of costs for the administration of insolvent estates. These areas have continued to cause a divergence of opinion among various stakeholders. For a fuller exposition, see J Tribe and S Hunt, 'The remuneration taboo', (2010) 23(9) Insolvency Intelligence 139-142. See also S Morgan, 'Insolvency office-holder remuneration: the practical aspects of fee approval, challenges and independent reviews' (2016) 29(6) Insolvency Intelligence 87-92, 91.
} 
the possible outcomes would be considerable. ${ }^{29}$ Since a wide range of outcomes would be conceivable, it would not always be possible to satisfy all of the creditors. ${ }^{30}$ The level of dissatisfaction felt by the creditor would largely depend on how realistic their desired outcome was, and what was the extent of their eventual losses. The dissatisfaction felt by the creditor may be further antagonised if the insolvency procedure was not perceived to be the best or the most viable option for the troubled company. ${ }^{31}$ Conversely, while these complaints may have contained some merit, they offer no grounds for challenging the IPs' proposals since the RPBs and their members have an on-going obligation to ensure that all creditors are treated fairly. ${ }^{32}$ Such is the importance of this obligation that failing to treat creditors fairly could lead to sanctions being applied against the IP. This could take many forms, that include the removal of the IP from the proceedings; partial conditions being placed on the IP so that they could continue with their work; and putting measures in place to direct the IP to make payments to the creditor when it would be in the public interest to do so. ${ }^{33}$

To that end, just as the creditors' interests are afforded some protection, the IP is entitled to make a claim for their remuneration. ${ }^{34}$ While the IP must be dissuaded by any undue influence and only make decisions based on sound judgement, ${ }^{35}$ there remains a general and persistent perception from creditors and the public alike that IPs make decisions that are

\footnotetext{
${ }^{29}$ Interestingly, decision trees are becoming part of the norm and can be used to assist the decision-making process in litigation. See S Burnett, 'Beyond grey hair and gut instincts: using decision trees to supplement analysis in litigation' (2006) 13(6) Int. C.R. 420-427.

${ }^{30}$ But the extent of a decision being unfair, whether one or a class of creditors were satisfied would depend entirely on the circumstances. See Revenue and Customs Commissioners v Portsmouth City Football Club Ltd (In Administration) Chancery Division [2010] EWHC 2013 (Ch) para 41.

${ }^{31}$ As was the case in Re BW Estates Ltd [2016] BCC 475, which stated that the creditors of a company that had been in administration were not entitled to an order that the remuneration of the administrators should be disallowed. The administrators had been entitled to conclude that the company could be rescued as a going concern and, save in relation to one matter, they had not acted unreasonably during the administration.

${ }^{32}$ See the Insolvency Service, 'Insolvency Practitioner Regulation - Regulatory Objectives and Oversight Powers, December 2015; members provide high quality services at a fair and reasonable cost, act transparently and with integrity, and consider the interests of all creditors, paras 4, 6; RPBs will be expected to tackle anti-competitive behaviour, abuse, including excessive fees, and misconduct through both monitoring and the proper assessment and thorough investigation of complaints from all sources, para 7 .

33 ibid 16.

${ }^{34}$ While the opinion about the extent of unreasonable, or even excessive, fees have been divided, it is clear that a review on IP's fees is required. See G Maynard-Connor, 'Officeholders' fees - the new reforms and their implications' (2015) 28(8) Insolvency Intelligence 113-114.

${ }^{35}$ For example, he must be able to provide valid reasons for his decisions, especially if the company cannot be rescued as a going concern or a better than winding up result cannot be achieved, see para 49(2)(b) of Schedule B1 of the Insolvency Act 1986. See further V Finch, 'Control and Co-ordination in Corporate Rescue' (2005) 25 Legal Studies 376.
} 
designed to attract higher fees. ${ }^{36}$ While there is evidence to support the view that opportunistic fees do occur, the extent to which over charging takes place would be difficult to determine since the Gateway does not investigate complaints that concern professional fees. ${ }^{37}$ Instead such grievances would be directed to the court, but if the evidence was circumstantial then the court would be reluctant to review. ${ }^{38}$ Therefore, the approach from the courts appears to be quite clear - IPs are free to make commercial decisions as they see fit, but the decisions that they make need to be readily justifiable and not designed to deliberately erode the funds that would be available to the creditors.

Therefore, the real difficulty is not with the fees claimed per se but with the way that some insolvency procedures have been used as a vehicle to charge excessive fees. For the creditors to claim that the fees were too substantial would not be a valid ground for a complaint, but if there was evidence of a deliberate intention to overcharge (where the regulation of fees was minimal or absent) then this would likely be identified as a valid complaint and the fee adjusted accordingly. However, to establish such an intention would be a difficult task given the position of unsecured creditors. Since most unsecured creditors would suffer some financial loss, but rarely would the IP not be paid (there may however be some discount applied), some creditors believe that the pursuit of profits are regularly put before their interests. This perception held by the creditors has in the past damaged the professional relationship between them and the IPs as it questions the competence, suitability and effectiveness of administrators, and liquidators. ${ }^{39}$ To address this concern, it has been imperative to ensure that IPs conduct insolvency work in a similar way. One way to achieve

\footnotetext{
${ }^{36} \mathrm{~A}$ press release from the Insolvency Service illustrates that there are companies out there that do alter their fees depending on what the company feels it could extract from the distressed company. See 'Recovery services company shut down following Insolvency Service investigation' (November 2016), <https://www.gov.uk/government/news/recovery-services-company-shut-down-following-insolvency-serviceinvestigation> accessed 25 March 2018.

${ }^{37}$ Hosted by the Insolvency Service, the Insolvency Practitioners' Complaints Gateway now acts as the single contact point for all complaints made against IPs. Upon receiving a complaint, the Insolvency Service will make a decision as to whether or not further investigation is warranted. If it is, the complaint will be referred to the relevant RPB and they will ultimately determine the complaint in accordance with new Common Sanctions Guidance.

${ }^{38}$ For example, see Re Cabletel Installations Ltd [2005] BPIR 28.

${ }^{39}$ For example, in Re Potters Oils (No2) [1986] 1 WLR 201; [1986] 1 All ER 890, the court concluded that on the facts there was nothing to show that remuneration fixed was so clearly excessive as to justify the court in interfering. In Re Orient Power Holdings Ltd [2009] BCC 452 the Potters decision was affirmed.
} 
this objective was to make it a requirement that IPs were to be qualified, ${ }^{40}$ regulated by a $\mathrm{RPB}$, and trained to establish that they were competent in fulfilling their duties. ${ }^{41}$

\subsection{The regulation of IPs: the role of the recognised professional bodies}

Since the UK's outdated insolvency system was thrown into the spotlight during the socioeconomic fallout when failed companies spiralled out of control in the early 1970s, the respective governments' response over the years has been to apply a private sector solution to "problems" like insolvency. ${ }^{42}$ One of the consequences to come out of adopting this approach was the replacement of the IPs regulatory bodies from the Official Receiver and the Insolvency Service (who is now the regulator of RPBs), ${ }^{43}$ to RPBs who are self-regulating and independent of the government. ${ }^{44}$ The change while it did reform some of the procedural inadequacies associated with the preceding system, it did not eradicate them all. A key criticism that was left to continue was the insolvency industry's intent to self-regulate, a desire that was demonstrated by its rejection for the need of an independent ombudsman to investigate and sanction disciplinary action or issue fines in relation to complaints that were substantiated against an IP or the respective RPB. ${ }^{45}$ The issue of self-regulation did not go unnoticed as the OFT's market review considered the possibility of creating an ombudsman scheme to investigate the conduct and regulation of IPs. The OFT recognised that from a qualification perspective many IPs originate from a legal or a financial background. On that basis, if it was decided that an ombudsman scheme or an independent complaints handler would be the most appropriate pathway to take, it would have been worth considering the possibility of extending an existing scheme's purview to cover the insolvency sector.

In response to the feedback received from the insolvency industry, a Complaints Gateway was set up in 2013 with the objective of increasing transparency in the complaint process. It should be noted that despite progressive steps being made to the complaint procedure, there

\footnotetext{
${ }^{40}$ Report of the Review Committee on Insolvency Law and Practice. (Cmnd. 8558 1982) (hereafter "Cork Report"), Part 2, Chapter 15. The qualification requirements will be discussed below.

41 IA 1986, part XIII.

42 T C Halliday \& B G Carruthers, 'The Moral Regulation of Markets: Professions, Privatization and the English Insolvency Act 1986' (1996) 21(4) Accounting, Organisations and Society 371-413.

${ }^{43}$ Who were housed in the Department for Trade and Industry (DTI).

44 The DTI now has a regulatory rule.

45 See the Insolvency Regulation Working Party, 1997, 1999. While no Insolvency Ombudsman currently exists, if a complainant is dissatisfied with the Insolvency Service's final response from the Chief Executive, the complainant can ask his Member of Parliament (MP) to raise his concerns with the Parliamentary Ombudsman. There is no direct route available.
} 
were limitations to the type of cases that would fall within the purview of the Gateway. For example, a valid complaint concerning remuneration would have to involve a failure to follow the correct process for charging or obtaining authorisation of fees, or that an IP had taken fees that were above their authorised amount. However, in relation to complaints that concerned the level of an IP's remuneration or expenses, the Gateway cannot review if the fee or fees involved were authorised before 1 October 2015.

The Gateway, since it has been in operation, has demonstrated that it would be possible to streamline the regulatory duties of the RPBs and collectively regulate them all in a similar manner. Given the ease in which this could be realised, the Gateway's ability to act as a single point of contact would suggest that the insolvency industry could scale down to one significant regulatory body in the near future. However, for this to occur there would have to be some restrictions to how this would take shape. For instance, the insolvency industry would be reluctant to establish an independent complaints body free from the Insolvency Service. This would be in spite of the likelihood that it would lead to efficient and consistent after-the-event complaint and review procedures, which would also go some way to restore creditor trust in the regulatory regime, and allow for a cost-effective route of fee assessment. ${ }^{46}$ Nonetheless, such a move would be unlikely to remedy any perceived unsecured creditor dissatisfaction as their frustration is inextricably tied to the statutory order of priority and the fee regime, which a single complaints body could not change. ${ }^{47}$ At the present moment further change would be doubtful, but should the RPBs fail to satisfy the Insolvency Service, the oversee regulator could use its power to enable a single RPB to replace the current system. ${ }^{48}$ Although concerns would remain about how accountable and transparent the complaint procedure is, the RPBs have shown a willingness to change. This can been seen in the overarching changes that have been accepted to the regulatory

\footnotetext{
${ }^{46}$ OFT, The Market for Corporate Insolvency Practitioners - a Market Study (June 2010) 7.

${ }^{47}$ R3, Section 3: An independent complaints body, 9 <https://www.r3.org.uk/media/documents/policy/policy papers/corporate insolvency/R3 responds to OFT recommendations.pdf $>$ accessed 3 March 2018.

${ }^{48}$ As stated above, under s144 of the SBBEA 2015 the Secretary of State reserves the power to establish a single regulator of IPs. This power would need to be used by October 2022 and any such move would be subject to consultation and further changes to the law. See the Insolvency Service's 2015 Annual Review of Insolvency Practitioner Regulation (March 2016) 4.
} 
framework that deal with the on-going concerns about the way in which IP fees are calculated and how IPs are regulated. ${ }^{49}$

In terms of how the RPBs should respond to complaints made against their IPs, it is evident that the existing regulation only intends to act as providing guidelines since a breach would not automatically give rise to disciplinary action or any penalty. ${ }^{50}$ In essence, as long as the IPs' actions could be broadly justified then the IP would be afforded the flexible to perform their functions as they see fit. ${ }^{51}$ This discretion, to conduct proceedings as "desired", has been interpreted widely, which has made it difficult to hold an IP accountable for their decisions that fall below the expected professional standards. While the industry has endeavoured to remain responsive in an ever-changing business world, the frequency in which independent reports have assessed the adequacy of insolvency practice have sometimes made the regulators efforts appear unsuccessful. As such, the distrust that creditors have regarding the decision-making process continue to tarnish the industry. Much of this has related to the insolvency industry persisting with the desire to self-regulate its IPs, and with it afford their members the wide discretion to self-determine how the law and related rules should be interpreted. Again, this opportunistic behaviour, which appears to be an industry norm, has been heavily influenced by the level of fees that could be attained from undertaking one statutory purpose over another. To this end, if the insolvency procedure provides great scope of the IP to make commercial decisions, the more opportunity there would be for the IP to decide how the insolvency will unfold.

\section{IP discretion: decision-making in administration}

The administration procedure allows for IPs to use their discretion to decide which statutory objective should be pursued, and how this objective would be achieved. The statutory objectives of administration can be located in paragraph 3 of Schedule B1 of the IA 1986. As a priority the IP must first consider whether the primary objective of rescuing the company as

\footnotetext{
49 This would include other processes such as pre-packaged administrations. For a discussion on the future of pre-packs see J Wood, 'The sun is setting: is it time to legislate pre-packs?' (2016) 67(2) Northern Ireland Legal Quarterly 173-88.

${ }^{50}$ S Frisby, 'Balancing Interests in Administration: Contributions from the Courts and the Coalface' (2009) 24(4) BJIB \& FL 198, 198.

51 In BLV Realty Organization Ltd v Batten [2010] BPIR 277 the court held that when an IP had made a commercial judgment, it was not for the court to interfere with such a decision unless it was based on a wrong appreciation of the law or was conspicuously unfair to a particular creditor or contractor. In Re CE King Ltd (In Administration) [2000] 2 BCLC 297 the court made it clear that they would not interfere with commercial decisions made by the administrator.
} 
a going concern could be considered. Should this option not be possible, nor could a better result be realised for the creditors, then the IP would be under an obligation to consider the alternatives. ${ }^{52}$ The amendments that were made by the Enterprise Act 2002 brought administration a step closer towards embracing Cork's vision to include early rescue efforts. ${ }^{53}$ However, the provisions did not define in detail whether "going concern" constitutes business or company rescue. The distinction between the two, while it may initially appear superficial, is critical to the understanding of what the main objective of administration aims to achieve. To rescue the business would be akin to a restructuring exercise (otherwise known as "hiving down") whereby the IP would downsize the company to the point where it could survive as a going concern. On the other hand, if a company rescue was pursued - a rescue procedure designed to keep the company intact (as opposed to simply restructuring the business), then this approach would likely face difficulties since limited change would result in the troubled company remaining as it was. At this point the second objective of administration, namely a better result for the creditors as a whole would be pursued. While some assistance on these distinctions can be drawn from complementary provisions, such as the DTI's explanatory notes,${ }^{54}$ it would ultimately be for the IP to decide what would be the purpose of the administration. ${ }^{55}$

However, while the IP can determine the objective of administration it is important to briefly note section 212 of the Insolvency Act 1986, and how the decisions made during administration could come under review should the company, for example, subsequently enter liquidation. Section 212 is a procedural provision that gives the court power to compel an administrator who has been guilty of any misfeasance or breach of any fiduciary or other duty in relation to the company in connection with carrying out their functions as liquidator to repay or contribute to the company's assets by way of compensation as the court considers appropriate ${ }^{56}$ As an office holder, an administrator owes a duty of care in the performance of

\footnotetext{
52 Para 3(1) provides a hierarchy of three specific purposes - in all administrations, whether instigated by an out of court appointment or by a court order. The purpose of this section is clear, the primary option must be considered first before the others are considered.

${ }^{53}$ Cork Report, para 198.

${ }^{54}$ The Department for Trade and industry was replaced in 2007 by Department for Innovation, Universities and Skills and Department for Business, Enterprise and Regulatory Reform. However, reference to the original text is still useful, see L Doyle and A Keay, Insolvency Legislation: Annotations and Commentary ( $5^{\text {th }}$ edn, Jordan Publishing 2016) at 785.

55 For a detailed overview of the purpose of administration, see J Wood, 'The objectives of administration' (2015) 36(1) Company Lawyer 1-7.

${ }^{56}$ s212(3) IA 1986.
} 
their duties to the standard of a reasonably skilled and careful IP. ${ }^{57}$ A high standard of care and diligence would be expected since the administrator would be entitled to take legal advice or submit to the court for guidance in instances where there was doubt or difficulty. ${ }^{58}$ To prevent a challenge the administrator would have been expected to have exercised their powers in good faith after taking proper advice. It therefore becomes apparent that should opportunistic behaviour be apparent at this stage, and the decisions that were made did not reflect the advice provided or it was in some way flawed, then the administrator could be found to have failed to identify relevant consideration or failed to use all proper care and diligence in obtaining information relevant to the instructions given or advice obtained. ${ }^{59}$ Any IP opportunism may be investigated and challenged by a successor IP, and if it was established that the IP acted out of self interest in the performance of their duties to secure secret profit out of dealings with the company then it is likely the court would intervene and take the necessary action against that IP. ${ }^{60}$

\subsection{The primary purpose: rescuing the company as a going concern}

The objective of rescuing the company as a "going concern" has been elucidated quite broadly. The term, while equivocal can derive some assistance from a comparison to the former section 8(3)(a) of the IA 1986 which referred to "the survival of the company, and the whole or any part of its undertaking, as a going concern" ${ }^{61}$ It is understood that the wording employed in paragraph 3(1)(a) of Schedule B1 of the IA 1986, should be construed as having the same meaning as that of the former section 8(3)(a) as interpreted in Re Rowbotham Baxter Ltd. ${ }^{62}$ That approach finds support in paragraph 647 of the DTI's explanatory notes which indicates that the objective of rescuing the company as a going concern "is intended to mean the company and as much of its business as possible". What constitutes "as much of its business" or what would be the minimum threshold to satisfy the test is not entirely clear. ${ }^{63}$

\footnotetext{
${ }^{57}$ Re Charnley Davies Ltd (No2) [1990] BCLC 760, 775.

${ }^{58}$ But it must be noted that the guidance sought from the court must be within reason as the courts are clear that they expect the IP to exercise their own judgement rather than rely on the approval of the court. See $R e$ MF Global UK Limited [2014] Bus LR 1156, para 41.

${ }^{59}$ For how the courts would approach misfeasance cases against office holders, see Top Brands Ltd v Sharma [2014] EWHC 2753 (Ch).

${ }^{60}$ Bristol \& West Building Society v Mothew [1998] Ch 1, 18.

${ }^{61}$ Re Rowbotham Baxter Ltd [1990] BCC 113, at 115E-F. See also Three Rivers District Council and others v Governor and Company of the Bank of England (No 4) [2002] EWCA Civ 1182, 201, 221.

62 ibid.

${ }^{63}$ However, when considering the prospects of achievement of any of the sub-purposes contained with the three objectives it would be critical to provide evidence for the court to assess, mere assertions would be insufficient for substantiating any claim. See Doltable Itd v Lexi Holdings Plc [2005] EWHC 1804 (Ch); [2006] 1 BCLC 384.
} 
Nor does section 8(3)(a) or the DTI notes make the point of distinguishing company and business rescue; in fact it implies that an element of both must be present. ${ }^{64}$ The wording does however explicitly acknowledge that when a company survives intact, but with no subsisting going concern undertaken, this would not fall within the scope of paragraph 3(1)(a) since, in line with paragraph 649 of the DTI's explanatory notes, a proposal resulting in nothing more than a "shell" company does not constitute rescue. ${ }^{65}$ Such an outcome would more than likely fall within the ambit of paragraph 3(1)(b).

The distinction between company and business rescue remains a fine one, but it is one that should nevertheless be appreciated. The rescue of the company itself would be a rare occurrence. In most cases the process has been designed to highlight aspects of the company that are not operating efficiently. Should an insolvent company be investigated it would be inevitable that some part of the company would be discarded to permit the company to attempt to continue as a going concern. Therefore, to streamline the company would be an act that aligns itself with business rescue, not necessarily rescue as intended by paragraph 3(1). The consequence of this would be that the IP is afforded wide discretion to determine the exact nature of the actions that are required, and with it, leave the creditors little option but to accept the proposed plan and the likely fees that the work would command. ${ }^{66}$

\subsection{Better result or the last resort - the alternative options to "rescue"}

The amended sub-paragraph encapsulated the previous duty on IPs whereby the receiver primarily owed duties to the appointing charge holder. The effect of paragraphs 3(1)(b) and 3(2) of Schedule B1 of the IA 1986 is that an administrator must perform their functions in the interests of the company's creditors (i.e. unsecured, secured and preferential creditors) as a whole. ${ }^{67}$ Amongst the creditors, they are required to perform their functions with the interests of unsecured creditors, weighing equally with those of preferential and secured creditors. This provision makes it compulsory for the administrator to consider objectives

\footnotetext{
${ }^{64}$ See generally para 3(1)(a)-(c) of Schedule B1 of the IA 1986.

${ }^{65}$ L Doyle and A Keay, Insolvency Legislation: Annotations and Commentary ( $5^{\text {th }}$ edn, Jordan Publishing 2016) 785.

${ }^{66}$ But it should be noted that in stating whether the statutory purpose could be achieved, the IP would be responsible for looking ahead at what could happen in the administration and not at any of the motives that may have led the directors to appoint them. This would likely be relevant when looking to the IP's own intentions. See Re BW Estates Ltd, Randhawa v Turpin [2015] EWHC 517 (Ch) 24.

67 Subject to sub-para (4), which provides the administrator the scope to act as they wished as long as they did not unnecessarily harm the interests of the creditors of the company as a whole.
} 
3(1)(a) and (b) in all cases, even when the level of secured indebtedness exceeds the value of secured assets.

Given the interests of different creditors it remains a concern, as indicated above, whether the term "creditors as a whole" would be sufficient in providing a workable basis for disgruntled unsecured creditors. Should a creditor wish to challenge the actions or proposed conduct of an administrator, the "unfairly harmed" ground under paragraph of Schedule B1 of the IA 1986, would be the most likely course of action. This would be particularly advisable where an administrator had been appointed by a floating charge holder and the appointee appears disinclined to pursue either of the objectives in paragraphs 3(1)(a) and (b) without justification. ${ }^{68}$ However, there would be no guarantees that such a challenge would be successful, especially since evidence would be required to prove that specific interests (often that of the complainants) had not been considered. ${ }^{69}$

Within $\mathrm{r} 3.2(\mathrm{~h})$ of the new IR 2016, the IP must disclose whether in their opinion the purpose of administration could reasonably likely be achieved. While this provides some scope for the IP to be flexible in their answer, they should be able to compile a statement of proposals under paragraph 49(1) of Schedule B1 of the IA 1986. This statement should explain how the purpose of administration would be achieved while, more specifically, paragraph 49(2)(b) of Schedule B1 of the IA 1986 requires an explanation to be included within the statement as to why the IP thinks that the objective in paragraph $3(1)$ (a) or (b) could not be achieved. ${ }^{70}$

\footnotetext{
${ }^{68}$ Despite the fact that administration is seen as attractive, see D Milman, 'Judicial Reflections in the Administration Process: a 2010 Perspective' (2010) 2 Co. L.N 283, it would appear that the liberal regime of the EA has promoted a tendency to embrace administration as "an exit route from over indebtedness" without any correlational entrepreneurial effort, see P Cranston, 'Fearful Silence' (2011) 24(2) Insolvency Intelligence 32. This highlighted concerns that the process could still be open to abuse, see P Okoli, 'Rescue Culture in the United Kingdom: Realities and the Need for a Delicate Balancing Act' (2012) International Company and Commercial Law Review 61, 62.

${ }^{69}$ See Holgate $v$ Reid [2013] EWHC 4630 (Ch). An application by creditors and members of a company for an order under para 74 of the Schedule B1 of the Insolvency Act 1986 directing joint administrators not to sell a company's assets, represented by a caravan park, and revoking the deemed approval of their proposal to do so was rejected where there was no evidence that the administrators had acted or were proposing to act either unfairly, or unfairly to harm the creditors' interests. The caravan park could not be operated as a viable business.

${ }^{70}$ It would not be necessary to identify in advance with certainty which of the statutory objectives could be achieved, see Hammonds (a firm) v Pro-fit USA Ltd [2008] 2 BCLC 159. The statement of the administrator's proposals would be produced for consideration by the creditors at the initial creditors' meeting, unless the IP sought deemed consent under paras 51 or 52(2) of Schedule B1 of the IA 1986, as amended by paras 10(4)-(6) of Schedule 9 of the SBEAA 2015; r3.38(4) IR 216. There is no prescribed form of the statement itself, although the statement must be attached to Form AMO3 (which replaced Form 2.17B on 6 April 2017), by virtue of r3.35 of the IR 2016, on being sent to the Registrar of Companies in compliance with para 49(4)(a). For further
} 
Balancing creditor interests and ensuring that the sub-purposes of administration are reasonably achievable would be decisions that require evidence. To determine whether a purpose would be possible would depend on whether the objective could be achieved. Should the intended purpose be capable of being achieved, but it would not be reasonable to do so as the impact on the creditors (in terms of time and costs) would make it undesirable, then the original intended purpose would be incapable of being classed as a justifiable course of action. While in most administrations the decisions left available to the IP would be limited, it is imperative that they demonstrate that measures had been taken (within reason) to increase the number of options left available to the company. To this end, the IP would be expected to perform their functions as quickly and efficiently as is reasonably practicable. ${ }^{71}$

However, it remains a concern that the discretion afforded to IPs leaves them with the scope to readily justify their decisions on commercial grounds. The discretion often puts the IPs' actions beyond scrutiny, and this position would likely face little challenge since creditors can now be bypassed with the deemed consent approach. ${ }^{72}$ The perceived lack of ability to question these decisions support calls (predominately from unsecured creditors) to further regulate the industry as on-going challenges raise questions regarding the assumed objectivity, competence and independence of the IP. ${ }^{73}$

\section{Key developments to address inadequate insolvency regulation}

This section provides a chronological overview of the main developments that have occurred within insolvency regulation since excessive fees were identified as a major concern in the Ferris Report. ${ }^{74}$ Since 1998 the regulation of IPs has become much more complex but it has not entirely eradicated behaviour associated with claiming excessive fees, nor has it prevented breaches that concern other regulatory issues. The following section provides a comprehensive outline of the key regulatory developments so that the thematic analysis can be fully appreciated.

detail, see L Doyle and A. Keay, Insolvency Legislation: Annotations and Commentary (Jordan Publishing 2016) 845.

${ }^{71}$ See the time constricting provisions contained in paras 76 and 77 of Schedule B1 of the Insolvency Act 1986. Collectively, they provide for the automatic ending of administration after one year, subject to extension.

${ }^{72}$ See r3.38(3) IR 2016. The administrator may seek a decision under the deemed consent approach, in which case r15.7 would also apply to the notice.

${ }^{73}$ V Finch, 'Insolvency Practitioners: The Avenues of Accountability' (2012) 8 Journal of Business Law 645. See also the OFT Market Study report and the Insolvency Service (2010).

${ }^{74}$ See the report of Mr Justice Ferris' Working Party on 'The Remuneration of Office Holders and Certain Related Matters' (London 1998) ("Ferris Report"). 


\subsection{The remuneration of office-holders: Ferris Report 1998}

The industry norm of over-charging on professional fees received notable attention in the Ferris Report which, amongst other things, urged that all parties (courts or other bodies) should look to the same criteria when fixing office-holder remuneration and that the overriding objective should be to provide IPs with reasonable, not minimal, remuneration. To achieve this objective Ferris indicated that remuneration should be reflective of a number of key factors, such as predictability, transparency and proportionality ${ }^{75}$ It is these three fundamental factors that remain highly relevant and continue to feature in literature that assess the UK's insolvency regulation regime.

The remuneration process came under scrutiny following Mirror Group Newspaper plc $v$ Maxwell. ${ }^{76}$ The fees claimed by the IP were so high that they were described as "profoundly shocking", especially since it transpired that there was "substantial rewards for the receivers and their lawyers [but]...nothing at all for the creditors of the estate". ${ }^{77}$ It was evident at the time that there was a general consensus within the insolvency industry to overlook creditors, a practice that led to IPs being portrayed as self-interested. Such a stigma begun to damage the integrity of insolvency proceedings and to that end alternative regulatory measures had to be explored. ${ }^{78}$ But despite the criticism that followed from Maxwell it was clear that IPs in general thought that the remuneration scale (fees set for work undertaken) was unrealistically low and so viewed the scale as a mere base from which negotiations could be entered into with creditors. This sense of entitlement to self-determine fees led to an industry-based practice that was widely perceived by the public to encourage, and ultimately rationalise, what is generally perceived as inappropriately high fees. ${ }^{79}$ The competing interests between IPs wanting to charge for their time irrespective of the value of the work undertaken and creditors wanting to control the level of fees led the Ferris Report to call for proportionate bounds to be applied. This approach required the IP to provide: clear justification for the main tasks undertaken; the reasons for carrying out, or preserving with, that work; and

\footnotetext{
${ }^{75}$ For further comments on the Ferris Report, see K Theobald, 'The Ferris Report' (1998) 14 IL\&P 300; G Lightman, 'Office-Holders' Charges' (1998) Insolvency Intelligence 1.

76 [1998] BCC 324.

77 Despite the criticisms related to high fees, the accountants were awarded 99 per cent of their claim and no wrongdoing was found. See Mirror Group Newspaper plc v Maxwell and Others [1999] BCC 684, 684, 686. 78 While the Maxwell case did concern an Official Receiver ("OR"), the scale referred to was applicable to others offices and was used in default of some other rate of remuneration being agreed. For further information, see V Finch, Corporate Insolvency Law: Perspectives and Principles (3 ${ }^{\text {rd }}$ edn, CUP 2017) 153.

${ }^{79}$ See Ferris Report, 50.
} 
evidence of the time spent on those tasks. ${ }^{80}$ In other words, the first major report which openly criticised IP remuneration and the way that the insolvency industry was regulated requested changes to be made to address the opportunistic behaviour associated with the way in which IPs calculated their fees. This resulted in greater regulation and directly led to SIP 9 (version 2 onwards), the Insolvency (England and Wales) Rules 2016, and the updated Part 6 of the 2018 Practice Direction on Office Holder Remuneration. ${ }^{81}$ The application and development of these reforms is demonstrated by the cases UIC Insurance Company Ltd (in provisional liquidation) $(\mathrm{Nol})^{82}$ and Simon v Brown, ${ }^{83}$ which highlight the very strict approach adopted by the courts in assessing, and ultimately, reducing IP fees.

\subsection{Market study: Office of Fair Trading 2010}

The Office of Fair Trading ("OFT") in its comprehensive study of the market for IPs examined their role and function, including their appointment, actions and fees. ${ }^{84}$ The OFT concluded, amongst other issues, that IPs made important decisions which often had adverse financial consequences on unsecured creditors. Since the IP had a great deal of discretion to make those decisions, it was considered important that the insolvency industry be regulated (in relation to both conduct and how fees were generated) to limit the scope for abuse. ${ }^{85}$ However, despite the existence of such regulation, unsecured creditors continued to be, in many situations, unable to constrain IPs' fees and actions. ${ }^{86}$ To better understand the insolvency industry the market study quite helpfully considered it useful to include the views of IPs. The response showed that 41 per cent of IPs believed that the regulatory system in place was ineffective in dealing with rogue IPs; 45 per cent believed that the system consistently failed to deal with poor behaviour, and 75 per cent did not consider that the existing regulations engaged creditors. ${ }^{87}$ The feedback illustrated that IP regulation required

\footnotetext{
${ }^{80}$ Ferris Report, para. 6.6. For further details, see C Swain 'He who pays the piper calls the tune administrators' remuneration under the new administration regime' (2004) 17(5) Insolvency Intelligence 7375. In light of the new fee regime, see S Morgan, 'Insolvency office-holder Remuneration: the Practical Aspects of Fee Approval, Challenges and Independent Reviews' (2016) 29(6) Insolvency Intelligence 87-92.

${ }^{81}$ The cases discussed under the earlier 2004 Practice Direction are likely to be still relevant, for example see Brook v Reed [2012] 1 WLR 416; Sallis v Hunt [2014] 1 WLR 1402.

82 [2007] BPIR 494.

83 ibid 412.

${ }^{84}$ Office of Fair Trading, The Market for Corporate Insolvency Practitioners - a Market Study (June 2010) <http://webarchive.nationalarchives.gov.uk/20140525130048/http://www.oft.gov.uk/shared oft/reports/Ins olvency/oft1245> accessed 1 March 2018.

85 ibid para 1.21 .

86 ibid para 1.22 .

87 ibid para 1.23.
} 
further reform to restore confidence in the insolvency industry - from both the creditor and IP perspective.

To achieve this end, a number of recommendations were proposed by the OFT ${ }^{88}$ The OFT recognised that there would be difficulties in bringing change, since the required change relied on being industry-led. It was therefore evident that effective regulation was only going to be possible if the RPBs monitored their IPs and enforced the new practice. This in turn would have gone some way to ensure that an accountable and flexible regulatory structure was in place that, for example, would suitably deal with unsecured creditors.

\subsection{Review of insolvency practitioner fees - Kempson Report $2013^{89}$}

Despite the recommendations proposed by the OFT concerning the function and regulation of IPs, both IP remuneration and the treatment of unsecured creditors continued to cause concerns. The practice of IPs inflating their fees (which at this stage continued to be an industry norm) had never been generally disputed by the Insolvency Service; nor would many within the insolvency profession dispute that there had been no cases that involved excessive fees. ${ }^{90}$ But any attempt to determine the true extent in which excessive fees were claimed has remained debateable; an issue that came to divide the opinions of creditors, IPs and academics alike. ${ }^{91}$ To decide whether the control mechanisms were sufficient to deal with cases that involved excessive fees proved to be a challenge since it was difficult to establish the true volume of such cases and whether the agreed figure was enough to pose a real concern to the insolvency market. ${ }^{92}$ The unknown scale of cases that could have involved excessive fees, to some degree, proved to be a major obstacle to regulation since the evidence

\footnotetext{
${ }^{88}$ The OFT, amongst other issues, advocated for the establishment of an independent complaints body to increase the efficacy and consistency of after-the-event complaint and review; implement measures to restore creditor trust in the regulatory regime; and enable a cost-effective route of fee assessment, see para 1.24 (a)(c). For a detailed overview of the new complaints structure, see V Finch, 'Insolvency Practitioners: The Avenues of Accountability' (2012) 8 JBL 645-667, 660.

${ }^{89}$ E Kempson, 'Reviewing Insolvency Practitioner Fees' (2013) <http://www.bis.gov.uk/insolvency/insolvencyprofession/review-of-ip-fees> accessed 1 March 2018.

${ }^{90}$ For example, see Re Cabletel Installations Ltd [2005] BPIR 28.

${ }^{91}$ For a general overview see D Milman 'Corporate insolvency in 2015: the ever-changing legal landscape' (2015) CLN 1; G Maynard-Connor 'Officeholders' fees - the new reforms and their implications' (2015) 28(8) Insolvency Intelligence 113-114.

92 r2.106(1) of the Insolvency Rules 1986 which allowed the court to fix administrator's remuneration for the whole of their term of office was replaced by the Insolvency (England and Wales) Rules 2016/1024 Schedule 1 para 1 (April 6 2017). The new provisions that deal with remuneration are now found in Part 8, rules 18.16 to 18.21 of the IR 2016, which requires the remuneration to be fixed as a percentage, by time, and/or as a set amount.
} 
base (identifiable cases where excessive fees are evident) was very thin. ${ }^{93}$ Despite the detrimental impact that excessive fees had on the reputation of the insolvency industry, little change was possible until the true extent of the problem was known.

In 2013 insolvency practitioner fees were finally reviewed in the Kempson Report. The report highlighted, amongst other things, that the existing insolvency codes of practice and the associated regime for compliance monitoring was inadequate when it came to remuneration. ${ }^{94}$ Kempson identified that there was a considerable lack of independent oversight to ensure that time charged was for work that was both necessary and properly performed. Within the cases reviewed by Kempson it was typical to find IP fees had been inflated through the use of administrative tasks. However, even though this practice was quite common in the industry, it was clear that it was not often challenged by the RPBs. ${ }^{95}$ Kempson accepted that the practice was both deliberate and common, referring to one commentator who quite candidly remarked that some IPs were "not afraid of charging a fee, but they work within the rules and their own moral compass". ${ }^{96}$ To ensure that the insolvency rules and the IPs" "moral compass" were kept in check, the Kempson report recommended that any fee that was deemed to be excessive should be referred to the court. If the fee was found to be unsubstantiated, then the fee could be disallowed by registrars in the courts who would ensure that there was some justification for the amount claimed. ${ }^{97}$ While some of the cases that were reviewed did not involve a substantial amount of money, the way in which the fees were calculated was enough to convince some creditors that the IP was merely concerned with how much they could extract from the insolvent company. ${ }^{98}$

\footnotetext{
${ }^{93}$ See Insolvency Service, 'Insolvency Practitioner fees: a review' (March 2014) $<$ https://www.gov.uk/government/publications/insolvency-practitioner-fees-a-review> accessed 18 March 2018.

${ }^{94}$ Kempson Report, 28-29.

95 For example, see Re Cabletel Installations Ltd [2005] BPIR 28, para 24, where work was carried out at too senior of a level and it was evident that there were lengthier meetings and excessive reviews than the administration warranted.

${ }^{96}$ Kempson Report, para 5.2.1.

${ }^{97}$ This has been part of the general principles since Re Independent Insurance Co Ltd (No. 2) [2003] 1 BCLC 640, paras 1.5, 3.

${ }^{98}$ Kempson raised a number of concerns relating to charges that had attracted a good deal of commentary, which included: charging for the time of work experience and trainee staff and for their training by more senior staff; charging for the time of secretaries and support staff carrying out routine tasks (e.g. for a cashier to raise a cheque and put it in the post).
} 
While an unsecured creditor could challenge a fee by applying to the courts, the cost and skill required to do so often acted as a deterrent. To address this obstacle Kempson recommended that a reasonable fee rate could be applied to insolvency work. Such a move was on the understanding that where controls were in place the level of fees would be considerably lower. ${ }^{99}$ However, the extent to which this would apply varies, since Kempson indicated that the OFT's estimate of the size of this reduction (nine per cent) was probably conservative, and in relation to the volume of cases, the report stated that the OFT's calculation that this applied to thirty-seven per cent of cases was likely be to an over-estimate. ${ }^{100}$

Notwithstanding the correct percentages it was possible to identify some cases where the fees had been successful challenged. ${ }^{101}$ Factors that had proven to be relevant included: reviewing what overheads were covered by headline hourly rates; the way in which time was recorded; identifying instances of failure to demonstrate that work undertaken was necessary, efficiently carried out, and properly performed. ${ }^{102}$ While the presence of these factors indicated that there may have been a deliberate intention to overcharge where the regulation of fees were minimal or absent, it was an overreach to suggest that the fees operated within a free market environment. ${ }^{103}$

In terms of the recommended changes, Kempson proposed that there should be greater oversight of how fees were calculated and, with this, a reduction in the number of complaints and challenges been brought before the courts. To address this, a simple, low-cost mediation and adjudication service for disputes concerning low-level fees was suggested as a possible way to ease the burden on the courts so that they could be left to deal with the complex cases involving larger sums of money. ${ }^{104}$ To ensure transparency played a key role in the process, independent oversight was stated to be a priority in both situations where there were

\footnotetext{
${ }^{99}$ Kempson Report para 6.

100 ibid para 5.1.

${ }^{101}$ For example, see Freeburn v Hunt [2010] BPIR 325; Hunt v Yearwood-Grazette [2009] BPIR 810; Re UIC Insurance Co Ltd (No2) [2007] BPIR 589; Re Cabletel Installations Ltd [2005] BPIR 28.

102 However, there are no time limits for an excessive remuneration/expenses challenge, see Re Calibre Solicitors Ltd (in administration) Justice Capital Ltd v Murphy and another (Administrators of Calibre Solicitors Ltd) [2014] All ER 187, para 17.

${ }^{103}$ While RPBs do not hear complaints that concern excessive professional fees, nor does the Complaints Gateway accept such complaints, the court can investigate and where necessary offer recourse.

104 The OFT made a similar recommendation in their market review report as did a report of research undertaken for the Insolvency Practices Council, see M Seneviratne and A Walters, 'Complaints handling by the regulators of insolvency practitioners: a comparative study' (Report to the Insolvency Practices Council, 2009).
} 
unsecured creditors and where no creditors' committee had been set up to examine the fees. For the purposes of achieving accountability and transparency it was deemed necessary to call on IPs to reduce the level of self-regulation that occurred within the insolvency industry. Such an adjustment would have been seen as a welcomed move aimed to restore creditor/investor confidence in insolvency procedures - an objective which was also promoted in the Ferris and OFT reports.

\subsection{The Insolvency Service consultation on strengthening the regulatory regime and fee structure for insolvency practitioners $2014^{105}$}

The 2014 consultation on the regulatory regime and fee structure (hereafter the "consultation") supported a number of suggestions contained in the earlier reports (Ferris, Kempson, OFT). The consultation made a number of proposals which aimed to address the three main strands identified in the Kempson report, namely enhanced monitoring and oversight of fees, increasing creditor engagement, and simplification of the fee charging structure.

In relation to the enhanced monitoring by the regulators, the consultation believed that the regulators could do more to ensure that fees charged by IPs represented value for money, in that the remuneration claimed by IPs properly reflected the nature and complexity of the work undertaken. ${ }^{106}$ The RPBs should actively monitor their IPs to ensure that they do not abuse their market position. ${ }^{107}$

In regard to creditor engagement the consultation found that the lack of input from unsecured creditors in the insolvency process often resulted in higher fees being claimed by the IP. ${ }^{108}$ The consultation proposed that unsecured creditors should be assisted by way of background/contextual information on fees generally. It was suggested that internet based

\footnotetext{
105 The Insolvency Service consultation 'Strengthening the regulatory regime and fee structure for insolvency practitioners' (2014) <https://www.gov.uk/government/uploads/system/uploads/attachment data/file/280880/Strengthening the regulatory regime and fee structure for insolvency practitioners.pdf > accessed 18 May 2018.

${ }^{106}$ Consultation (2014) para 98.

107 ibid para 101.

108 ibid 3. For a general discussion see P Bailey, 'Insolvency Service consults on insolvency practitioner fees and IP regulation' (2014) CLN 1-4; C Umfreville and P Walton, 'Insolvency Practitioner fees in the UK - all alone in the world?' (2014) 27(6) Insolvency Intelligence 86-91.
} 
information could assist creditors by providing information on how to appoint an IP, how to get involved in negotiating fees, and the best way to obtain competitive quotes. ${ }^{109}$

The last strand considered was how the fee structure could be simplified. Concerns from the Kempson report were considered and in light of this the consultation recommended that the use of time and rate as a basis for remuneration should be restricted to cases where there was tight control over the work being done. This would ensure that the creditor could have an expectation that fees charged would be based on the value of the work done by the IP. ${ }^{110}$ As an alternative, it was proposed that IPs should take their remuneration either as a percentage of realisations or as a fixed fee in all insolvency cases subject to a number of exceptions. ${ }^{111}$

In terms of the impact that this consultation had on future reforms, it set the foundation for the changes implemented by the Small Business, Enterprise and Employment Act (SBEEA) 2015, the Insolvency Service: regulatory objectives and oversight powers 2015, along with the Insolvency (England and Wales) Rules 2016.

\subsection{Small Business, Enterprise and Employment Act (SBEEA) $2015^{112}$}

The introduction of the SBEEA has made it possible to amend the number of RPBs; meaning that despite the recent reduction in the number of RPBs from seven to five, in future, the number could actually increase. ${ }^{113}$ Nevertheless, upon reviewing the proposed regulatory objectives a further reduction in the number of professional bodies would be the more likely outcome. Set within section 138 of the SBEEA, the overall objective of the 2015 Act is to secure the fair treatment for persons, reflect modern regulatory principles, and ensure consistent outcomes across similar insolvency cases. ${ }^{114}$ It is hoped that such a framework would encourage an independent and competitive insolvency market with IPs providing high quality services at a cost to the recipient which would be fair and reasonable; that would be transparent and with integrity; considers the interests of all creditors; and protects and

\footnotetext{
${ }^{109}$ Consultation (2014) para 105.

110 ibid para 107.

111 Ibid para 113.

112 Part 10 of the SBEEA 2015, is entitled: Regulation of insolvency practitioners: amendments to existing regime between ss137-146 and sets out the new law concerning the regulatory regime.

113 s391 of the IA 1986, as amended by s137 of the SBEEA 2015. This section outlines the application for recognition as a RPB.

${ }^{114}$ s391C, sub 3(a)(i)-(iii) of the IA 1986, as amended by s138 of the SBEEA 2015.
} 
promotes the public interest. ${ }^{115}$ Furthermore, and in response to the previous reports (Ferris, OFT, and the 2014 consultation), the meaning of regulatory principles contained in section 138 of the SBEEA, are now inserted in a new section 391C(4) of the IA 1986, which states that regulatory activities should be transparent, accountable, proportionate, consistent and targeted only at cases in which action would be needed. In terms of ensuring that the RPBs comply with their obligations, the Secretary of State can in certain circumstances intervene and if necessary reprimand the RPB. ${ }^{116}$ In extreme cases where the RPB has failed in its regulatory function and objectives, the Secretary of State has a new power to revoke the RPB's recognition under section 391(6) of the IA $1986 .{ }^{117}$

In addition to this new power to revoke recognition, the Secretary of State can according to section 391(4) IA 1986, as amended by section 144 of the SBEEA, establish a single body to regulate IPs. Such a power covers two possibilities: creating a new body or selecting an existing body that takes over the duties of the other RPBs. ${ }^{118}$ With the creation of this power it is possible that a single regulator could be afforded the responsibility for monitoring and training all IPs; something that would do much to encourage a consistent approach across the insolvency industry.

\subsection{Insolvency Service: regulatory objectives and oversight powers 2015}

\subsubsection{Overview of regulatory objectives}

The oversight powers introduced a number of key measures aimed at addressing the concerns raised in the 2014 consultation. The measures included: reaffirming regulatory objectives for insolvency regulators; introducing new powers for the Insolvency Service to take action against RPBs and their members when it was in the public interest; and to change the way that some fees and expenses were charged by IPs. In considering these powers there were two things to note. First, in the context of a creditor making a complaint about the conduct of an IP, and the complaint was subsequently referred to the respective RPB by the complaint

\footnotetext{
115 s391C, subs 3(b)(i)-(iii), and 3(d) of the IA 1986, as amended by s138 of the SBEEA 2015.

${ }^{116} \mathrm{~s} 391 \mathrm{~J}$ of the IA 1986, as amended by S139 of the SBEEA 2015. The procedure is set out in s391K of the IA 1986, as amended by s139 of the SBEEA 2015.

117 See s391L of the IA 1986, as amended by s140 of the SBEEA 2015; with the procedure listed under s391M, as amended by s140 of the SBEEA 2015.

118 See s145 of the SBEEA 2015. For this option to occur the Secretary of State must be convinced that the assigned body is able and willing to exercise the functions conferred by the regulations, and the body has arrangements in place relating to the exercise of those functions which are such to be likely to ensure that the conditions in subsection (2) are met.
} 
gateway (hereafter "Gateway"), there was a considerable amount of uncertainty as to what investigative process constitutes fair treatment to the complainant. ${ }^{119}$ Second, the Insolvency Service has made it clear that the powers do not attempt to address all of the issues, situations and circumstances that may arise. Instead the powers intend to be merely suggestive to how the RPBs might go about meeting their regulatory objectives. ${ }^{120}$ It would therefore seem that the oversight powers afford the RPBs with a certain level of discretion as to how they might regulate their members. This discretion, to a large extent, permits the RPBs to continue to self-regulate the insolvency industry, and in some respects dictate the pace of insolvency reform. However, given the regulatory concerns already discussed, there are a few sections in the oversight powers that are worth further examination.

\subsubsection{Fair treatment, regulatory principles and consistent outcomes}

While RPBs have traditionally had procedures in place to identify any malpractice relating to fees, there is now an explicit requirement for RPBs to encourage their members to provide services at a fair and reasonable cost. To demonstrate compliance with this objective, a RPB would need to consider and demonstrate that it acted on complaints made in relation to the level of IP fees and other associated costs. To determine what response would be adequate in this context would likely involve having regard to both the interests of IPs, who would be entitled to a fair remuneration for their services, and those affected by the fees charged.

Generally, it would be considered that the RPBs have, for example, contemplated whether the fees charged by their members have been set at the appropriate level when the liabilities and assets realised have been taken into account. To determine whether this has occurred, and deal with any complex issues concerning the valuation of certain assets, RPBs may also need to consider whether suitable expertise had been used, and whether the insolvent company had been dealt with in a timely fashion. ${ }^{121}$ To assess claims on this basis would encourage a best practice approach, to ensure that IPs act transparently, with integrity and that they always

\footnotetext{
${ }^{119}$ Much of the decision making and explanations have been left to the RPB to use their expertise and judgement to decide what is fair treatment in an insolvency context. See Insolvency Service, 'Insolvency Practitioner regulation - regulatory objectives and oversight powers (December 2015). Legislative changes introduced on 1 October 2015, at 6.

120 lbid at 4.

${ }^{121}$ For example, according to para 4 of Schedule B1 of the IA 1986, the administrator must perform his functions as quickly and efficiently as is reasonable practicable. However, to determine whether the IP has acted too slow would be difficult to substantiate since what should be done by the administrator is a commercial decision that is afforded wide discretion, see Re CE King Ltd [2000] 2 BCLC 297, 302-3.
} 
consider the interests of all creditors as a whole. ${ }^{122}$ While these principles are for the most part already embodied in the working practices of RPBs, compliance with these principles remain essential since consistent breaches could determine whether or not the RPB retains its recognition.

\subsubsection{Revocation of a RPB's recognition}

As briefly stated above, the oversight powers provide the Insolvency Service with the newfound power to revoke a RPBs' ability to give recognition to IPs. ${ }^{123}$ The powers could be used where, for example, a body no longer wished to act as a RPB, or the Insolvency Service was satisfied that as a result of actions or omissions by a RPB it was clear that the regulatory objectives would not be met, and so in the circumstances it would be appropriate to revoke recognition. ${ }^{124}$ In regard to the latter position, if a RPB had a sustained record of regulatory breaches by its members and it was clear that a lack of suitable action had been taken by the $\mathrm{RPB}$, then this would likely be enough to convince the Insolvency Service that the RPB in question was not capable of meeting the expected standards. The ability for the Insolvency Service to intervene would therefore offer some much needed oversight of the RPBs to ensure that they do fully comply with their regulatory obligations.

\subsection{Insolvency (England and Wales) Rules $2016^{125}$}

To address concerns associated with the fee regime, new rules were introduced on 1 October 2015 that required IPs to provide an estimate of their fees for when they proposed to charge on a time and rate basis. The Insolvency (Amendment) Rules 2015 ("IR 2015"), ${ }^{126}$ and all the previous versions, were replaced by the Insolvency (England and Wales) Rules 2016 ("IR 2016”). The relevant section that relates to fee estimates can now be found in Part 18 of the IR 2016.

\subsubsection{Fee estimates}

Part 18 of the IR 2016 provides guidance on how an estimate should be compiled, with the aim of creating a fee framework that would be more fair and transparent than under the

\footnotetext{
${ }^{122}$ For example, through the Insolvency Code of Ethics, and the Statement of Insolvency Practice (SIPs) England and Wales.

123 This would require a statutory instrument to be made.

124 Insolvency Practitioner regulation - regulatory objectives and oversight powers (December 2015) 15.

125 Insolvency Rules 2016 (SI 2016/ 1024).

126 The Insolvency (Amendment) Rules 2015 (SI 2015/443).
} 
previous fee regime. Given that a RPB could have its recognition revoked for failing to meet the required professional standards, RPBs are likely to take a keen interest in the fee estimate process and lookout for any signs that they have been manipulated. To this end, RPBs would be expected to review the number of occasions in which an IP has made a request to the creditors to increase their fees, or instances where the IP has never made such a request, since both actions could indicate behaviour that is associated with over-charging on the estimate. Conversely, the new rules should not prevent or limit the circumstances in which a RPB could examine fees. Even if the fee amount was near the original estimate, the focus would be to review and determine whether the estimated fee was "fair and reasonable" and not simply whether the final estimate reflected the original fee claimed. Whether the practice of providing estimates would bring a greater level of accountability and transparency to the fee regime remains to be seen. It would be suspected that the level of additional regulation required to monitor the fee estimates would be substantial and as a consequence administratively unworkable. For example, while the IR 2016 encourage IPs to submit accurate estimates at an early stage in the administration process, ${ }^{127}$ there would be some apprehension towards how the industry should regulate over-estimates. While over-estimates could potentially lead to the remuneration not being approved, should the IP be able to justify the fee estimate, and the relevant guidelines have been complied with, ${ }^{128}$ it would be difficult for creditors to convince the court to intervene. ${ }^{129}$ It is worth noting that the IR 2016 represent a move away from the government's original proposal, which was to abolish time costs altogether where there was no secured creditor or creditors' committee. The IR 2016 have instead removed the need for creditors' meetings unless they were requested by ten creditors or ten per cent of creditors in number or value. ${ }^{130}$ Without creditor meetings it would undoubtedly make it more difficult for IPs to discuss fee estimates with creditors.

For IPs the change has led to a new approach to how they claim their fees. Since much of the additional administrative work generated by the new proposal remains unknown, some form of quality control mechanism would have to be introduced to monitor the process of how

\footnotetext{
${ }^{127}$ Which also includes IPs seeking to charge on a time costs basis in an administration, creditors' voluntary liquidation (CVL), compulsory liquidation or bankruptcy.

${ }^{128}$ For example, SIP 9, which provides guidelines on the basis of remuneration and suggests what information should be provided to creditors.

129 The cases have shown that the courts have stepped in where an office-holder's actions provided no benefit to the estate., Re Edennote Ltd [1996] BCC 718, 720; Mitchell v Buckingham International plc [1998] 2 BCLC $369,390-391$.

${ }^{130}$ s246ZE IA 1986, as amended by S122 SBEEA 2015.
} 
estimates are reviewed. This may be undertaken by either the Gateway (if its scope for receiving fee complaints is widened), the Insolvency Service, or a collaboration between the Gateway and the RPBs. The review process would likely involve comparing the initial estimate with the actual time incurred at different stages of the proceedings, and assess whether the charges are fair, reasonable and warranted. ${ }^{131}$ It is quite possible to foresee sanctions being applied to IPs who deliberately over estimate their fees, but much would depend on whether the IP could robustly justify the estimate and what information would be required in the report following the updated SIP $9 .{ }^{132}$

To assess the potential effect of the new rules, in 2014 the Department for Business, Innovation and Skills (as it was then called) ${ }^{133}$ conducted an impact assessment exercise and identified that further estimates were likely in approximately fifty per cent of administrations, illustrating that the practice of providing estimates would likely present an ongoing learning process for the profession. ${ }^{134}$ Such rules would likely provide unsecured creditors with further suspicion that professional fees could be inflated due to the way estimates were compiled.

\subsubsection{Deemed consent and electronic communication}

Sections 246ZF and 379ZB of the IA 1986 (as amended by section 122 of the SBEEA 2015) provide for a significant change in how the decisions of creditors would be taken in all insolvency proceedings. These sections together with Part 15 of the IR 2016 flesh out an entirely new decision making regime. Critically, the change removes the need for formal, and often costly, creditors' meetings with a process of "deemed consent". ${ }^{135}$ The IP would be expected to write to creditors with the proposals and include a deadline for registering

\footnotetext{
${ }^{131}$ A similar regime has been in use in Australia for some time. This will be explored towards the end of this article.

132 The new SIP 9 came into force $1^{\text {st }}$ December 2015. Para 11 states that when providing a fee estimate the office holder should supply that information in sufficient time to facilitate that body making an informed judgement about the reasonableness of the office holder's requests. Fee estimates should be based on all of the information available to the office holder at the time that the estimate is provided and may not be presented on the basis of alternative scenarios and/or provide a range of estimated charges.

${ }^{133}$ Since July 2016 the Department for Business, Innovation \& Skills was replaced by the Department for Business, Energy \& Industrial Strategy.

${ }^{134}$ See Impact assessment on Insolvency Practitioner fees - up front estimates', BIS (2014) 10 <https://www.gov.uk/government/uploads/system/uploads/attachment data/file/408834/IA IP fees final1.pdf> accessed 25 March 2018.

135 ss246ZF and 379ZB IA 1986, as amended by s122 SBEEA 2015. Further detail of how this provision works is set out in rules 3.38 and 15.7 IR 2016.
} 
objections. The proposals, which include remuneration and expenses, would be deemed "approved" provided that at least ten per cent of creditors by value did not object. ${ }^{136}$ Should any objection satisfy the threshold, modernised methods of communication such as email, virtual meetings and electronic voting could be used to resolve matters wherever possible (although a creditor could still request a formal, in-person meeting). ${ }^{137}$ In that instance, the final creditors' meeting would be replaced with email correspondence.

The IR 2016 has been designed to lessen the regulatory burden on IPs, to streamline the insolvency process by placing a greater emphasis on the use of technology, and to reduce the amount of complaints that the Gateway receive in relation to the lack of communication between creditors and IPs. ${ }^{138}$ Such initiatives plan to introduce greater use of ecommunication and online platforms throughout the insolvency process. ${ }^{139}$ IPs would be encouraged to upload and share documents with creditors on websites in an attempt to reduce the volume of paper going through the mail.

These "process" changes are expected to reduce the professional costs associated with an insolvency procedure, leaving more funds to be distributed to creditors. However, it would appear that the "deemed consent" concept has reduced the need for creditor participation, since the lack of participation from creditors could be seen in itself as sufficient evidence to show that the proposal was approved due to their lack of objection. The removal of automatic creditor participation in the insolvency process would likely pose some interesting questions as to who would be in a position to challenge IP remuneration, and whether these changes present further opportunity for the IP to control and define the scope of insolvency procedures.

\section{An alternative view: regulation in Australia}

Until recently insolvency regulation in Australia was similar to that found in the UK.

However, the Australian Insolvency Law Reform Act 2016 has changed this position and

\footnotetext{
136 Ibid, s246ZF(6) of the IA 1986, as amended by s122 SBEEA 2015.

${ }^{137}$ ss246ZE and 379ZA IA 1986.

${ }^{138}$ Communication breakdown between the IP and creditors remain one of the leading complaints received by the Gateway.

${ }^{139}$ Such as completing documents in electronic form. The only requirement is that it could be read by the recipient and reproduced in hard copy if necessary, see r1.4 IR 2016.
} 
with it raised questions as to whether the Australian Act has over-regulated the profession. ${ }^{140}$ The reform was driven by the need to control and monitor how IP fees were generated. In this respect, the Australian Insolvency legislation was very similar to the UK since insolvency cases were normally charged on a time-cost basis, ${ }^{141}$ and it was noted that attendance by unsecured creditors meetings were also generally low. The Australian Restructuring Insolvency \& Turnaround Association (ARITA), ${ }^{142}$ which is the country's leading specialist group on matters concerning insolvency, stated at the time that in most administrations a fee based upon time spent would be appropriate. ${ }^{143}$ For time costs to apply the reform provided that IPs seek approval from creditors subject to a specified cap or maximum amount. If the cap was to be exceeded then the IP would have to first obtain the creditors' consent. ${ }^{144}$ In terms of the preferred approach, the Australian system had not favoured a percentage of realisations methodology or fixed fees. ${ }^{145}$ Instead much had depended on whether a secured creditor existed to influence the level of fees claimed by the IP.

The lack of engagement from creditors in the UK's administration process had often led to IP fees being left unchallenged. ${ }^{146}$ Some changes have occurred in recent years with the Insolvency (Amendment) Rules 2015 (SI 2015/443) now designed to mirror the system found in Australia. ${ }^{147}$ This requires IPs who act in an administration to give clear estimates to creditors in their progress reports of the likely charges for fees and expenses, and if necessary, to warn creditors if the figure was likely to increase. Based on this approach, the UK's intention was to increase the level of information being conveyed to the unsecured creditor so that they could be part of the decision making process, similar to that found in Australia. $^{148}$

\footnotetext{
140 The Act came into force on $1^{\text {st }}$ March 2017.

${ }^{141}$ Agreed either by the Courts or creditors, with the right for creditors (amongst others) to apply to Court to review the remuneration. See $\mathbf{5 0 4}$ of the Australian Corporations Act 2001, which lists the matters the court will take into account upon a review of a liquidator's remuneration.

142 Formerly known as the Insolvency Practitioners Association of Australia (IPAA).

143 The third edition of the Professional Code <http://insolvencyresources.com.au/IPAA/Code 009a-code-3rdedition---final-ipa-version.pdf $>$ accessed 23 April 2018.

${ }^{144}$ ARITA Code of Professional Practice, s15.2.2.

${ }^{145}$ C Umfreville and P Walton, 'Insolvency Practitioner fees in the UK - all alone in the world?' (2014) 27(6) Insolvency Intelligence 88.

146 ibid 90.

${ }^{147}$ This was highlighted by the Kempson Report, paras 6.1.2 and 6.1.4.

148 ibid para 6.1.2.
} 
The Australian Senate enquiry into IP conduct was prompted, in part, by concerns about the levels of remuneration of IPs. An enquiry by the Economic References Committee of the Australian Senate explored market solutions in their report entitled: the regulation, registration and remuneration of insolvency practitioners in Australia: the case for a new framework. ${ }^{149}$ The report made a number of recommendations that were designed to promote further regulation within the insolvency industry. Of these proposals cited it was suggested a "flying squad" that consisted of accountants or other qualified individuals would be responsible for conducting investigations into a sample of IPs. ${ }^{150}$ With some IPs selected at random, others with the aid of a risk profiling system and market intelligence, the randomness of the reviews would ensure that the regulation of the profession was wide. This approach would encourage IPs to perform their duties at the highest standards on the chance that their decisions could be scrutinised. Others key recommendations included: to make IPs renew their license every three years; ${ }^{151}$ that as part of the proposed licensing system, the insolvency regulator could suspend a liquidator's license if they believed overcharging had occurred; ${ }^{152}$ and that the new insolvency regulator should work with the IPAA and the Institute of Chartered Accountants to ensure that IPs comply with the remuneration report template as set out in the IPAA Code of Professional Practice. ${ }^{153}$ Collectively, the recommendations highlighted the need to ensure that the insolvency market was monitored to a standard that assured that the best decisions would be made for the creditors, and not for the personal benefit of the IP. However, it should be noted that there were cases in Australia which suggested that "commercial decisions" by administrators would, like in the UK, attract little inference from the court. ${ }^{154}$

\section{Recommendations}

\subsection{One recognised professional body to regulate all IPs}

There remains a lack of consistency with how the RPBs oversee the regulation of their members. A move to reduce the number of RPBs has already been witnessed when the

\footnotetext{
${ }^{149}$ The full report, which was published by Parliament of Australia in September 2010 <http://www.aph.gov.au/Parliamentary Business/Committees/Senate/Economics/Completed inquiries/200810/liquidators 09/report/index> accessed 23 March 2018.

${ }^{150}$ See the 'Regulation, Registration and Remuneration of Insolvency Practitioners in Australia: the case for a New Framework' (2010) recommendation 3, para 11.18.

151 ibid para 11.29 .

152 ibid para 11.57.

153 ibid para 11.62.

${ }^{154}$ Robit Nominees Pty Ltd v Oceanlinx Ltd (in liq) (rec and man apptd) [2016] FCA 225.
} 
Solicitors Regulation Authority (SRA) ceased to authorise their members at the end of 2015. While the RPBs have now been reduced from seven to five, there is no reason why the number of regulators could not be further reduced. ${ }^{155}$ Apart from the historical differences between the RPBs there remains little to be gained from approximately 1735 IPs being monitored by five different RPBs. In comparison the SRA has been able to successfully govern solicitors under one regulatory body despite having some 135,309 members. ${ }^{156}$ On the other hand, the Bar Council, which is perhaps more similar in size and structure to that of the insolvency service's position as overseer of the RPBs, permits the professional Inns to discipline its members. ${ }^{157}$ On this point, it would be feasible for the RPBs to modify their practice to follow the way in which the Inns' disciplinary functions are carried out, which is currently conducted by a joint Council that consists of members from across the Inns of Court. To adopt a common approach to disciplinary action would be a small, but nevertheless an important step, towards harmonising the procedures of the RPBs and an act that would bring the IPs together under a singular regulatory system.

The legislative changes introduced as part of the 2015 regulatory objectives and oversight powers permitted the revocation of a RPBs recognition. The extent of this power would cover both a professional body that no longer wished to act as a RPB, and give the power to the Insolvency Service to revoke recognition to RPBs that looked likely to fail in achieving the regulatory objectives. ${ }^{158}$ It is quite possible that over the next few years the Insolvency Service, with the knowledge that a single regulator could be introduced in place of the current system, could take action against any RPB that persistently fail. ${ }^{159}$ Should the RPBs be reduced to one, and a common simplified fee structure be created, this would go some way to convince creditors that insolvency procedures (including fees) were approached in a consistent manner across the market. Nonetheless, as the Kempson report illustrated, there would be difficulties with putting this into practice, with a key issue being whether to apply

\footnotetext{
${ }^{155}$ In a previous article it was suggested that the RPBs should be merged to form one regulatory body, namely the Association of Responsible Insolvency Practitioners (ARIP), see J Wood, 'The sun is setting: is it time to legislate pre-packs?', Northern Ireland Legal Quarterly (2016) 67(2) 173-88.

${ }^{156}$ As stated by the SRA's latest statistics, <http://www.sra.org.uk/sra/how-wework/reports/data/population solicitors.page> accessed 5 February 2018.

157 The statistics from the Bar Council indicate that in 2018 there were 15,899 practicing barristers. Membership across the four Inns of Court include: Lincoln's Inn had approx. 21,000 members; Inner Temple 8,000; Middle Temple 5,000; and Gray's Inn 5,500.

158 Insolvency Service, 'Insolvency Practitioner Regulation - Regulatory Objectives and Oversight Powers (December 2015) 15.

${ }^{159}$ See the Insolvency Service's 2015 Annual Review of Insolvency Practitioner Regulation (March 2016$) 4$.
} 
charges for specific aspects of casework, for example using fixed fees for statutory duties and time rates only for investigative work. ${ }^{160}$ A concern that could become apparent would be that "investigative work" could maintain a level of ambiguity leaving the IP once again with the discretion to seek opportunities in failed businesses.

\subsection{Introduce "flying squads" to assess IPs professional qualities}

The Insolvency Service has demonstrated that it would, when required, amend the regulatory framework and fee regime to reflect a more accountable and transparent approach to insolvency law. In order to ensure that IPs comply with the relevant regulation, "flying squads" like that discussed by the Australian Senate, could be established by the Insolvency Service. The elite squad could include a selection of members from the RPBs, and they would be responsible for investigating a random, or specified, sample of IPs.

To construct the squad, it would be envisaged that a small secretariat would be required, which would control membership of the squad. The secretariat would be responsible for selection, training, monitoring and performance evaluation. Close inspection of the selection process would be critical to ensure that a high level of independence was maintained. The objective of the squad would be to promote quality and confidence in the insolvency system. The squad members when reviewing decisions would have to ensure that they were not influenced, against better commercial judgement, to accept a proposal when it should have been discredited. The distribution of cases assigned to the squad would be rotated to promote transparency. However, it would be inevitable that while all squad members would have a sufficient level of expertise, some would likely possess specialised knowledge that would place them in a better position to make a decision concerning certain insolvent companies. Such occurrences would likely be quiet rare as most companies fall under a similar business structure. Nonetheless, the main focus would be for the Insolvency Service to insist on a strict rotation basis that would unfortunately, despite its best intentions, add an unrealistic burden to the process.

If, on the other hand, squad members were referred to the secretariat, not all would be familiar with the review process, or the expectations for that particular role. With strict time

\footnotetext{
${ }^{160}$ The Insolvency Service consultation, 'Strengthening the regulatory regime and fee structure for insolvency practitioners' (2014) 27.
} 
restraints in place for squad members to review proposals, it would have the potential for poor decisions to be made that were not commercially sound. Given the nature of administration, time would be of the essence, and as such there would be some apprehension that too much expectation would be placed on the squad members. In terms of liability, while it would be unlikely attached to any member, it would be difficult to predict how such a case would unfold if a creditor pursued a claim against a squad member for having overlooked or intentionally weakened the original position. Should litigation follow, it would likely lead to the conclusion that the IP would remain responsible.

The publication of the opinion of the squad and the viability review of the proposal would reveal details as to whether they agreed with the proposal. The report would not be able to reveal any sensitive information that could prevent any future amendments to failed proposals, which subsequently could be accepted. The value placed on such reports would depend and vary according to the input of different squad members. In order to limit discrepancies between different squad reports, it would be advisable to introduce some standardised practice so that the level of discretion is controlled. A time restriction recommending that the squad does not spend more than half a day reviewing such contents would ensure that each proposal is reviewed in a consistent manner. Finally, the report should be detailed enough to offer concise recommendations as to whether the proposals were viable and reasonable, thereby permitting the industry to review its own progression.

\section{Conclusion}

It continues to be of critical importance that insolvency regulation remains effective and responsive to the concerns expressed by creditors and investors alike. Changes that are made within the insolvency landscape should aim to ensure that the regulation of the insolvency industry evolves and is ready to deal with insolvent companies of the future. While there have been a number of regulatory developments over the last few years, namely the SBEEA 2015, the 2015 oversight powers, and the IR 2016, it would be premature to determine whether they have had the desired impact on the regulation of IPs.

One aspect where the increased level of regulation will be significant would be the use and application of the "fee estimate", and whether this would be successful in being able to deter excessive fees. The requirement of an estimate would have no doubt put IPs on notice that their fee proposals would be scrutinised to a greater degree. While the additional measure 
could lead to an increase in challenges from creditors, it also has the potential to standardise industry practices when it comes to fees. This would be well received by some unsecured creditors, but others would likely remain sceptical as to whether an increase in regulation equates to more effective measures that protect their interests. Some creditors would likely continue to question the validity (and safeguards) of a system that affords IPs with such a wide discretion to determine the outcome of an insolvent company. However, their concerns would not necessarily rest with the fact that IP discretion exists, but with the extent of it. The discretion afforded to an IP is wide enough to justify most decisions, and there remains a concern as to how effective the Gateway would be in dealing with breaches committed by the IP.

At the core of this article it was asked whether the UK's regulatory framework was effective at deterring opportunistic behaviour. To address this question, it was necessary to draw a correlation between regulation that was designed to deal with excessive fees, and measures that were designed to deal with other regulatory issues such as IP conduct. While the two regulatory objectives are distinct in nature, they share a common purpose as the opportunistic behaviour of IPs' charging excessive fees has often been treated as an industry norm. This norm is the product of an industry that insists on remaining self-regulated; a factor that continues to apply despite the revocation measures introduced in the SBEEA 2015 and the oversight powers 2015 .

Despite the increased regulation of IPs there remains a wide scope for the IP to use their discretion to make commercial decisions that are difficult for creditors to challenge. The administration procedure illustrated the extent of which IP discretion could be used the objective of administration was considered. To substantiate what exactly constitutes rescue, and at what point could the purpose of rescuing a company as a going concern be achieved relies almost entirely on the objective opinion of the IP. The wording of paragraph 3 of Schedule B1 of the IA 1986, provide a technical outline of what the objectives of administration are but it does not provide any intricate detail of how this should be determined. Instead there is a complete reliance on the IPs' interpretation of concepts such as "rescue" and "going concern", leaving the extent to which that objective could be achieved to the discretion of the IP. While the extent to which IPs could use their discretion would vary on the circumstances, commercial decisions are often rationalised with ease. With this in 
mind greater insolvency regulation is futile if it does not address the level of discretion afforded to the IPs

It would therefore be prudent for future reform to focus on the conduct of RPBs and the way that they review their members use of discretion. Creditors who would want to challenge an IP decision may attempt to rely on the court for assistance but they would likely receive little support since the courts have shown a reluctance to interfere with commercial decisions.

While this position may not help creditors, it should be seen as an endorsement of the correct legal position; that IPs have been afforded wide discretionary powers to undertake insolvency work, and that the courts should not second guess commercial decisions. Nonetheless, while there are some cases that show that the courts would in certain circumstances intervene, for example, where there was evidence that excessive fees had been claimed, the level and scope of judicial intervention remains minimal.

To this end, the use of discretion has allowed IPs to manipulate the law for their own purposes, and this practice has found itself embedded in the modern insolvency industry. Whether the recent regulation will be able to deter opportunistic behaviour within a procedure like administration remains to be seen, but for as long as the IP retain their discretion, the effectiveness of insolvency regulation will continue to be questioned. 